Proceedings

\title{
Creative Tools: How Education and Arts Connect? ${ }^{\dagger}$
}

\author{
Ana Catarina Pereira \\ Communication and Arts Department, University of Beira Interior, 6201-001 Covilhã, Portugal; \\ anacatarinapereira4@gmail.com \\ + Presented at the 2nd Innovative and Creative Education and Teaching International Conference \\ (ICETIC2018), Badajoz, Spain, 20-22 June 2018.
}

Published: 21 November 2018

\begin{abstract}
It is a question with which surely many university professors debate: what turns a Cinema professor into a good College Professor? Obliterating the subjectivity of the adjectivation, I believe that this is the ultimate goal of every academic or professional who has embraced the career of specialized art and cultural education. Nevertheless, the undefinition or constant debate around concepts such as Art, New Media, History, Canon, Experimentalism, Utopia or even Freedom, often associated with film schools, raise the question. How to properly define the programs of the curricular units? How to establish evaluation criteria? How to meet the expectations of a whole faculty that considers an immense variety of issues fundamental for the knowledge and development of students of the first degree in universities?
\end{abstract}

Keywords: university; Canon; art

\section{Introduction}

The introduction should briefly place the study in a broad context and define the purpose of the work and its significance.

Let us begin with the archetypes. What, in a collective imagination, corresponds to the figure of the university professor? A figure distant from the audience, sitting in a pulpit, lecturing on his/her specific subjects of research and dedication. In front of him/her, an audience is fixed on the still figure, absorbing his/her knowledge with the wide notion of the privilege of the moment. I wonder if we are not being vaguely outdated. This figure still exists, in some moments and in certain faculties. But it corresponded essentially to a time when technologies had not yet invaded the classrooms and, above all, the day-to-day of the students who are now part of the same public. In recent years, studies on concentration ability have multiplied. Simultaneously, constant appeals to the teachers are made for the integration of the mentioned technologies in class, with a dynamic that intercepts spectators accustomed to the proliferation of images and the disconnection of a subject in just a few seconds.

These studies are, however, essentially aimed to pedagogical practices on primary and secondary education, for which there is still little academic reflection on teaching in Higher Education. For instance, let us do the exercise of consulting the program of the two editions of ICETIC: how many communications were presented on the subject? Let us also consult academic journals and other international congresses of pedagogy and we quickly conclude that the subject is not recurrent. From this absence we can then infer a first conclusion to be drawn from our brief presentation: there are numerous academic studies and reflections on pedagogical practices at previous levels of education, but few on pedagogical practices pertaining to that same level. The Academy thus focuses little on itself, with little self-evaluation exercises. 


\section{Brief Looking to the Higher Education}

The fact that college education is optional in Western countries, and that it is generally associated with a view of its frequency as a prerogative leading to an in-depth knowledge, questioner and promoter of specific competences, can be pointed out as the main justification for this absence studies, theses or debates. The student of Higher Education thus corresponds to the archetype of the intellectual who pursues studies and theoretical and practical training, motivated by a spirit of commitment, dedication and constant motivation. I also wonder about the real possibility of generalization of the archetype, as well as about its lack of timeliness.

As a brief biographical note, it will also be pertinent to assume that this presentation is part of my own experience as a university professor and course director, in the areas of Cinema and Cultural Studies. In this sense, I do not present formulas, but rather the brief questions of a teacher in permanent formation, who keeps the expectation of constant learning throughout the future and expected years of activity.

The case study presented here concerns the regency of the course "Programming and Organization of Cultural Events", at University of Beira Interior, over the last three years, which is the motto for a brief dissertation on objectives that can be stipulated for the practicing of future cultural agents. The attempt to balance the theoretical and practical aspects, as well as the need to prepare students for the job market-in which, once it is a final year course, they are expected to attend in the following months-have dictated the evolution of this experience.

In addition, it is understood that in Higher Education - particularly in the aforementioned courses of an artistic and cultural nature-the debate is particularly urgent, given the significant number of teachers with a course that did not support pedagogical training. We refer, in particular, to teachers who started their career after (or in parallel with) a course as researchers or professionals in essentially performing areas, such as Communication Sciences or Cultural Sciences, Music, Theatre, Cinema, Law, Dance, Design, among others. In these cases, the challenge of teaching or training is twofold, due to the lack of previous experience that gives them specific pedagogical skills, distinct from the apprehension of public speaking techniques, more easily acquired in private workshops and sessions. The entrance into the classroom is thus, in most cases, stimulated by mimetic processes, in an attempt to reproduce the habits and tendencies of previous models of former teachers; or, on the opposite side, by the negative, creating a model that rejects the practices in which they had previously taken part.

\section{International Directives}

Of all the questions that we seek to launch here, we also highlight the specificity of Higher Education in relation to previous levels of education. The fact that it is frequented mainly by young adults makes it impossible to transpose methods and techniques aimed at children or adolescents, even though they are more demanding at all levels. On the other hand, we have seen, as we have already mentioned, that this is the degree to which the least attention has been paid. The figure of the university professor risks therefore to freeze the model of the researcher who also teaches, when the European directives are made in the opposite direction.

In Portugal, as in most European countries, the implementation of the so-called "Bologna Process" has been taking place since 2006/07, requiring and generating new training paradigms, both for the shortening of the graduation period as for accentuating of the masters' view as a fundamental complement of the professionalization. A brief analysis of the Bologna Declaration, (e.g., [1]), signed by the Ministers of Education of 29 European countries on 19 June 1999 highlights several topics, such as the promotion of university education with uniform European standards, facilitating the international mobility of teachers and cooperation between institutions. Continuous learning of students and teachers is also encouraged, less in a sense of the transmission of knowledge than in the promotion of autonomy.

Previously, the World Declaration on Higher Education for the 21st Century (UNESCO 1998, e.g., [2]) had already pointed out principles complementary to those stipulated by Bologna. In article 1 it is emphasized that Higher Education should: “(a) educate highly qualified graduates and 
responsible citizens able to meet the needs of all sectors of human activity, by offering relevant qualifications, including professional training, which combine high-level knowledge and skills, using courses and content continually tailored to the present and future needs of society."

Considering the mentioned references, let us then focus on the training of future programmers and cultural managers. In the curricular unit taught to the third year of the course of Cultural Sciences, I contact with finalist students of the first cycle, who are, in many cases, performing internships or who have already had sporadic experiences in the labor market in this area. The established general objectives dictate that, at the end of the teaching-learning process, the student understands the role of the cultural programmer in the contemporary artistic panorama, manifesting a critical sense in relation to the contents and formats of cultural programming. To this end, it must be able to implement a cultural programming project with several institutional partnerships.

The evaluation of each student is based on several moments, some of them developed individually, and others in a group, namely: an interview conducted and presented in class, directed to a cultural programmer whose functions and activities arouse the specific interests of each one. The "place of self" thus seeks to be compatible with the integrative perspective, which Paulo Freire alludes to when he says: "one of the most important tasks of educational-critical practice is to provide the conditions in which learners in their relations with one another and everyone with the teacher or teacher rehearses the deep experience of taking over. To assume as social and historical being, as being thinking, communicating, transforming, creator, dream maker, able to be angry because able to love. Assume yourself as subject because you can recognize yourself as an object. Assumption of self does not mean exclusion from others. It is the 'outreach' of 'not $\mathrm{I}^{\prime}$, or of you, that makes me assume the radicalism of myself." (Freire 2015, p. 42, e.g., [3]). At the original: "uma das tarefas mais importantes da prática educativo-crítica é propiciar as condições em que os educandos em suas relações uns com os outros e todos com o professor ou a professora ensaiam a experiência profunda de assumir-se. Assumir-se como ser social e histórico, como ser pensante, comunicante, transformador, criador, realizador de sonhos, capaz de ter raiva porque capaz de amar. Assumir-se como sujeito porque capaz de reconhecer-se como objecto. A assunção de nós mesmos não significa a exclusão dos outros. É a 'outredade' do 'não eu', ou do tu, que me faz assumir a radicalidade de meu eu." (Freire 2015, p. 42, e.g., [3]).

Individually or in groups, students should also organize a cultural event, inside or outside University. The results of the strategy designed and implemented are, finally, eclectic, heterogeneous, with different levels of versatility and quality. Beyond the university building, cultural activities were promoted in different associations of the counties of Covilhã, Belmonte and Fundão, in the villages, towns and cities; for children, youths, diversified or senior citizens; in schools, homes, amphitheaters, sports pavilions, rural houses, abandoned buildings, public gardens, libraries, museums and even in a castle, with a starry sky illuminating a fado night.

We do not have, in the conclusion that we can withdraw from these early years, any pretension to prescribe pedagogical methods or formulas. Only the notion that a participation in an Education Congress can relaunch the debate: how can we seek to improve the pedagogical skills of Higher Education teachers, distancing us from the model of researcher-lecturer?

Conflicts of Interest: The author declares no conflict of interest.

\section{References}

1. BOLONHA. The Bologna Declaration of 19 June 1999. Available online: https://www.eurashe.eu/library/ modernising-phe/Bologna_1999_Bologna-Declaration.pdf (accessed on 4th June 2018).

2. UNESCO. World Declaration on Higher Education for the Twenty-First Century: Vision and Action. Paris, 9 October 1998. Available online: http://www.unesco.org/education/educprog/wche/declaration_eng.htm (accessed on 4 June 2018). 
3. Freire, P. Pedagogia da Autonomia: Saberes Necessários à Prática Educativa; Editora Paz e Terra: São Paulo, Brazil, 2015.

(c)

(C) 2018 by the author. Licensee MDPI, Basel, Switzerland. This article is an open access article distributed under the terms and conditions of the Creative Commons Attribution (CC BY) license (http://creativecommons.org/licenses/by/4.0/). 